\title{
Co-expression of SOX2 and HR-HPV RISH predicts poor prognosis in small cell neuroendocrine carcinoma of the uterine cervix
}

Shi-Wen Zhang ${ }^{1,2+}$, Rong-Zhen Luo ${ }^{1+}$, Xiao-Ying Sun ${ }^{3+}$, Xia Yang ${ }^{1}$, Hai-Xia Yang ${ }^{1}$, Si-Ping Xiong ${ }^{1}$ and Li-Li Liu ${ }^{{ }^{*}}$

\begin{abstract}
Background: Small cell neuroendocrine carcinoma of the uterine cervix (SCNEC) is a rare cancer involving the human papilloma virus (HPV), and has few available treatments. The present work aimed to assess the feasibility of SOX2 and HPV statuses as predictive indicators of SCNEC prognosis.

Methods: The associations of SOX2 and/or high-risk (HR)-HPV RNA in situ hybridization (RISH) levels with clinicopathological characteristics and prognostic outcomes for 88 neuroendocrine carcinoma (NEC) cases were analyzed.

Results: Among these patients with SCNEC, SOX2, P16 $6^{\text {INK4A }}$ and HR-HPV RISH expression and SOX2/HR-HPV RISH co-expression were detected in 68(77.3\%), 76(86.4\%), 73(83.0\%), and 48(54.5\%), respectively. SOX2-positive and HRHPV RISH-positive SCNEC cases were associated with poorer overall survival $(O S, P=0.0170, P=0.0451)$ and diseasefree survival (DFS, $P=0.0334, P=0.0309$ ) compared with those expressing low SOX2 and negative HR-HPV RISH. Alternatively, univariate analysis revealed that SOX2 and HR-HPV RISH expression, either separately or in combination, predicted the poor prognosis of SCNEC patients. Multivariate analysis revealed that the co-expression of SOX2 with HRHPV RISH may be an independent factor of OS [hazard ratio $=3.597 ; 95 \%$ confidence interval (Cl): $1.085-11.928 ; P=0.036$ ] and DFS [hazard ratio $=2.880 ; 95 \% \mathrm{Cl}: 1.199-6.919 ; P=0.018$ ] prediction in SCNEC.

Conclusions: Overall, the results of the present study suggest that the co-expression of SOX2 with HR-HPV RISH in SCNEC may represent a specific subgroup exhibiting remarkably poorer prognostic outcomes compared with the expression of any one marker alone.
\end{abstract}

Keywords: SOX2, HR-HPV RISH, P16 ${ }^{\text {INK4A }}$, SCNEC, Prognosis

\footnotetext{
* Correspondence: liulii@sysucc.org.cn

†'Shi-Wen Zhang, Rong-Zhen Luo and Xiao-Ying Sun contributed equally to this work.

'Department of Pathology, Sun Yat-sen University Cancer Center, Guangzhou 510060, China

Full list of author information is available at the end of the article
}

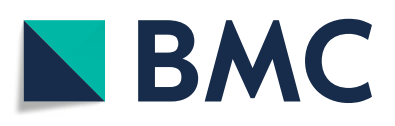

(- The Author(s). 2021, corrected publication 2021. Open Access This article is licensed under a Creative Commons Attribution 4.0 International License, which permits use, sharing, adaptation, distribution and reproduction in any medium or format, as long as you give appropriate credit to the original author(s) and the source, provide a link to the Creative Commons licence, and indicate if changes were made. The images or other third party material in this article are included in the article's Creative Commons licence, unless indicated otherwise in a credit line to the material. If material is not included in the article's Creative Commons licence and your intended use is not permitted by statutory regulation or exceeds the permitted use, you will need to obtain permission directly from the copyright holder. To view a copy of this licence, visit http://creativecommons.org/ licenses/by/4.0/. The Creative Commons Public Domain Dedication waiver (http://creativecommons.org/publicdomain/zero/1. 0/) applies to the data made available in this article, unless otherwise stated in a credit line to the data. 


\section{Introduction}

Small cell neuroendocrine carcinoma of the uterine cervix (SCNEC) is a highly aggressive and rare malignant cervical cancer $(<3 \%)$. The incidence of lymph node and distant metastases is high in the early stage of SCNEC, although SCNEC is usually only detected at the advanced stage [1-3]. SCNEC has a poor prognosis, which is closely related to the stage at diagnosis. Particularly, the 5-year survival rate for early SCNEC cases is 30$46 \%$, while it is only $0-15 \%$ for patients at the advanced stage [4]. Despite the increase in multidisciplinary therapies, patients with advanced SCNEC still have a poor prognosis [5]. Therefore, it is important to improve SCNEC prognosis.

The sex-determining region Y-box 2 (SOX2) gene, located on chromosome 3q26.3-q27, belongs to the SOX family [6]. Notably, SOX2 has been recognized as a potent transcription factor involved in self-renewal, maintenance of stem cell properties, and pluripotency in embryonic stem cells $[6,7]$. SOX2 plays a vital role in tumor development, progression, and cell survival in various cancer types [8-10]. A few studies have reported that SOX2 is overexpressed in cervical squamous cell carcinoma (SCC), and plays an important role in the progression from squamous dysplasia to SCC. The expression of SOX2 is correlated with the degree of differentiation of SCC, and upregulation of SOX2 has been shown to enhance cervical cancer cell invasion and migration in vitro $[11,12]$. The small infiltrating cancer nests surrounding CIN 3 margins or the CIN 3-like SCC with deep invasion generally display a decreased SOX2 level locally, and this indicates reduced SOX2 expression during invasive growth [13]. SOX2 has been reported to be related to HPV infection in previous studies $[14,15]$. However, its expression, clinical significance and the association between SOX2 and HPV status in SCNEC have not been evaluated.

Numerous studies have demonstrated a closed etiopathogenetic relationship between the development of cervical cancers and high-risk (HR) human papilloma virus (HPV) infection [16]. The occurrence of SCC and adenocarcinoma is associated with HPV16 infection, while that of SCNEC is associated with HPV18 infection [17]. HPV infection is detected using a variety of approaches, such as polymerase chain reaction (PCR), immunohistochemistry (IHC), and in situ hybridization (ISH) $[18,19]$. Previous studies have shown that HPV mRNA detection and $\mathrm{P}^{16}{ }^{\mathrm{INK} 4 \mathrm{~A}} / \mathrm{Ki} 67$ IHC are valuable biomarkers for HPV oncogenic expression [20]. The detection of mRNA expression indicates changes at the molecular level, and mRNA amplification becomes a poor prognostic factor when persistently infected with a highly oncogenic type, such as HPV 18 [21]. Furthermore, HPV mRNA expression, detected using HR-HPV RISH, in SCNEC has not been investigated extensively.
The present study retrospectively examined the expression levels of SOX2 and HPV mRNA in SCNEC and investigated the relationships between the expression levels and clinicopathological characteristics in SCNEC cases.

\section{Materials and methods \\ Patients and samples}

In the present retrospective study, we enrolled 88 patients with histologically confirmed SCNEC, who had under surgical resection at Sun Yat-sen University Cancer Center between January 2010 and December 2014. Patients were enrolled when they were diagnosed with primary SCNEC, with available clinical information. The last follow-up was conducted in June 2020. The study protocol was approved by the Institutional Ethical Board of Sun Yat-sen University Cancer Center. The raw data relevant to the study were imported into the Research Data Deposit public platform (www.researchdata.org.cn; RDD approval number: RDDA2020001710).

\section{Tissue microarray (TMA) establishment and IHC}

SCNEC tumor tissues and lymph node metastatic tissues, were obtained to construct a TMA. Thereafter, the constructed TMA block was sectioned (thickness, $4 \mu \mathrm{m}$ ) and stained for immunohistochemical analyses. Sections were de-waxed in xylene and ethanol and treated with $3 \%$ hydrogen peroxide diluted with methanol. Thereafter, avidin-biotin was used to block all sections overnight at $4{ }^{\circ} \mathrm{C}$. The sections were then incubated with anti-SOX2 (ab134154, Abcam), anti-P16 ${ }^{\text {INK4A }}$, antiSynaptophysin (GT206529), anti-Chromogranin A (ZA0507, Zhongshan, China), anti-CD56 (ZM-0057, Zhongshan, China), anti-MSH6 (SP93) (Roche, Germany), anti-MLH1 (Roche (M1), Germany), antiPMS2 (Dako (EP51), Germany), anti-Ki-67 (ZA0502), and anti-MSH2 (ZA0622, Zhongshan, China) antibodies. Phosphate buffer was used to wash the sections three times before incubation with biotinylated goat antimouse antibodies. Next, DAKO liquid 3, 3'-diaminobenzidine tetrahydro-chloride (DAB) was used for staining, and Mayer's hematoxylin was used for counter-staining. The block-like and diffuse staining at every core was positive for P16 ${ }^{\mathrm{INK} 4 \mathrm{~A}}$, whereas the patchy or non-stained sections indicated a negative result. Additionally, $\geq 1 \%$ positively-stained cancer cell nuclei indicated a positive result for MSH2/MSH6/PMS2/MLH1. The SOX2 positive samples were scored as follows: $0,<5 \%$ cells with positive staining; $1,5-24 \%$ cells with positive staining; 2 , 25-49\% cells with positive staining; $3,50-74 \%$ cells with positive staining; and 4, 75-100\% cells with positive staining. Positive staining intensity was graded as follows: $0,1,2$, and 3 suggested negative, weak, moderate, and strong staining, respectively. Then, the percentage 
score was multiplied by the intensity score to obtain the eventual score. Thereafter, 6.5 was used as the median IHC score to classify high or low SOX2 expression levels.

\section{HPV subtypes}

According to a previous study, the tumor tissues used in PCR should not be the same as those used in TMA [22]. HPV was detected using the Roche Cobas 4800 system (Pleasanton, CA), and the following 14 subtypes of HPV DNA were detected: $16,18,31,33,35,39,45,51,52,56$, $58,59,66$, and 68 .

\section{HPV E6/E7 mRNA in situ hybridization}

The RNAscope scoring system was used to examine each specimen, as described in previous studies [23, 24]. HPV fluorescent in situ hybridization was performed using a chromogen and the RNAscope system (Advanced Cell Diagnostics; catalog no. 312598). The RNAscope probe HPV HR18 contains probes that target E6 and E7 mRNA in these high-risk subtypes: HPV16, 18, $26,31,33,35,39,45,51,52,53,56,58,59,66,68,73$, and 82. The RNAscope results were classified into five degrees based on the following scoring guidelines: 0 , no staining or $<1$ dot in 10 cells (40x); $1,1-3$ dots in each cell (20-40x); 2, 4-10 dots in each cell as well as a few dot clusters (20-40x); 3, > 10 dots in each cell as well as dot clusters in $<10 \%$ positive cells $(20 x) ; 4,>10$ dots in each cell as well as dot clusters in $>10 \%$ positive cells (20x). An RNAscope score $\geq 1$ indicated positivity.

\section{Statistical analysis}

The SPSS 19.0 software was used for data analyses. The expression of SOX2 in different SCNEC subgroups was compared using an unpaired T-test. Correlations of SOX2 and P16 $6^{\mathrm{INK} 4 \mathrm{~A}}$ with the HPV mRNA expression levels and clinicopathological parameters in patients with SCNEC were analyzed using the chi-square test. Kaplan-Meier analysis was used to analyze overall survival (OS) and disease-free survival (DFS), while the logrank test was used for comparison. The correlation of prognosis was analyzed using univariate and multivariate Cox regression analyses. $P<0.05$ (two-sided) indicated statistical significance. To construct a nomogram, the predictive power of each variable for OS and DFS was evaluated using univariate Cox regression. Thereafter, the significant variables were used in multivariate Cox analysis. To determine independent prognostic variables, the Akaike information criterion (AIC) score was used for backward selection for suitable variables. Finally, the variables were enrolled for the nomogram construction, with 1-, 3-, and 5-year OS and DFS selected as the primary endpoints. To evaluate the nomogram predicting power, a concordance index (C-index) with receiver operating characteristic (ROC) curve analysis was applied [25]. The discrimination of the predicted values from the actual values was visualized by generating calibration curves for 1- and 3-year OS data [26].

\section{Results}

\section{Patient characteristics}

The characteristics of 88 patients with SCNEC are summarized in Table S1. Sixty-six patients (SCNEC-alone, 75\%) presented with only small cell carcinoma components, and Twenty-two patients (SCNEC-mix, 25\%) presented with small cell carcinoma mixed with other epithelium-derived tumors (SCC, adenocarcinoma, and others) were noted. There were 79 (89.8\%) and $9(10.2 \%)$ cases at FIGO stages I-IIA and IIB-IV, respectively, and a median 30.6-month follow-up was conducted to examine OS and DFS.

\section{Expression of SOX2 and P16 $6^{\mathrm{INK} 4 \mathrm{~A}}$ in SCNEC tissues was detected using IHC}

To confirm the SOX2 and P16 ${ }^{\mathrm{INK} 4 \mathrm{~A}}$ expression profiles in SCNEC, a total of 88 paraffin-embedded SCNEC tissue samples, with the corresponding clinicopathological data, were harvested to construct the TMA cohort. SOX2 was primarily located in the nucleus, while P16 ${ }^{\mathrm{INK} 4 \mathrm{~A}}$ was observed in the cytoplasm (Fig. 1a and b). SOX2 expression levels within tumor tissues were observed and classified as negative, weak, moderate, or strong staining (Fig. 1a). Among these patients with SCNEC, SOX2, P16 ${ }^{\mathrm{INK} 4 \mathrm{~A}}$, and HR-HPV RISH were detected in 68(77.3\%), 76(86.4\%), and 73(83.0\%), respectively (Fig. S1A). Furthermore, the positive expression rates of SOX2 in the SCNEC-alone and SCNEC-mix groups were $72.7 \%(48 / 66)$ and $90.9 \%(20 / 22)$, respectively. SOX2 expression was not significantly different between groups $(P=0.1660)$ (Fig. S1B).

\section{Expression of HPV mRNA in SCNEC was detected using the RNAscope technique}

In situ expression of HPV mRNA was detected using RNAscope and scored accordingly. HPV mRNA was detected predominantly in the cytoplasm of cancer cells with variable staining intensity. The scores of 0 to 4 and the proportions of T1-4 are shown in Fig. 1c and d. The HPV mRNA-positive rate was $86.4 \%(76 / 88)$ in patients with SCNEC, and the expression rates in SCNEC-alone and SCNEC-mix were $81.8 \%(54 / 66)$ and $100 \%(22 / 22)$, respectively (Fig. S1A and S1C). T-test analyses indicated $(P=0.2118)$ no significant difference between the groups (Fig. S1C). Another TMA contained 37 SCNEC cases with lymph node metastases. There was no significant difference in the HPV mRNA expression between primary tumor and lymph node metastases $(n=37 ; P=$ 0.1134) (Fig. S1D and S1E). Furthermore, the 


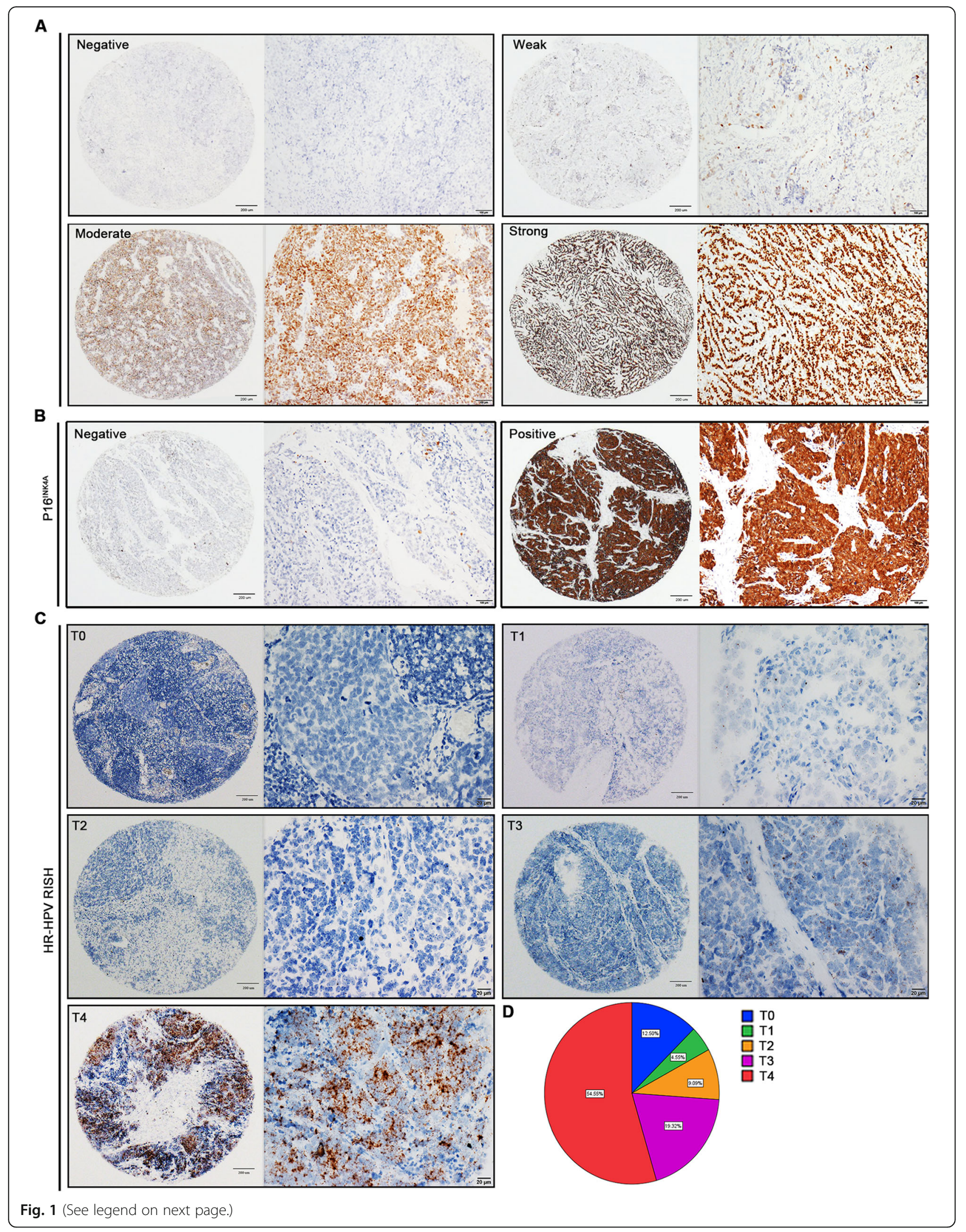


(See figure on previous page.)

Fig. 1 Expression of SOX2, P16 $6^{\text {INK4A }}$, and HR-HPV RISH in SCNEC. a Immunohistochemical staining showing the SOX2 level in tissue microarray (TMA), with negative, weak, moderate, and strong intensity staining. $\mathbf{b}$ Negative and positive immunohistochemical staining for P16 $6^{\text {INK4A }}$ expression in tumor tissues. c HPV mRNA was detected using HR-HPV RISH in tumor tissues (T). Representative images of scores 0 (T0), 1 (T1), 2 (T2), 3 (T3), and 4 (T4) are shown. $\mathbf{d}$ The proportion of HR-HPV RISH scores in SCNEC tissues

proportions of the combinations of HPV tests, SOX2IHC and P16 ${ }^{\text {INK4A }}$ expression levels are shown in Fig. S1F-I and Fig. S2.

Relationship between SOX2, P16 ${ }^{\mathrm{INK} 4 \mathrm{~A}}$, and HPV mRNA The association of SOX2, P16 ${ }^{\mathrm{INK} 4 \mathrm{~A}}$, and HPV mRNA expression with the clinicopathological characteristics in SCNEC is summarized in Table 1. SOX2 expression within tumors was significantly related to vascular invasion $(P=0.023)$ and relapse $(P=0.023)$, whereas SOX2 expression showed no significant correlation with other clinicopathological features of patients with SCNEC. However, P16 ${ }^{\mathrm{INK} 4 \mathrm{~A}}$ expression was only significantly related to Ki67 $(P=0.005)$. Notably, HPV mRNA levels were significantly correlated with FIGO staging $(P=$ $0.021)$, pre-operative chemotherapy $(P=0.007)$, relapse $(P=0.027)$, neuroendocrine markers $(P=0.021)$, and pathological classification $(P=0.014)$. These data suggest that the overexpression of SOX2 and HPV mRNA potentially facilitates tumorigenesis and development of SCNEC.

\section{SOX2 and HPV mRNA influenced the prognosis of patients with SCNEC}

Tables 2 and 3 present the univariate and multivariate Cox hazards regression results, respectively. Univariate regression analysis suggested that HPV DNA, stromal invasion, parametrium invasion, nerve invasion, SOX2, HR-HPV RISH, SOX2/P16 ${ }^{\text {INK } 4 A}$, and SOX2/HR-HPV RISH were related to patient OS $(P<0.05)$. Moreover, multivariate Cox regression showed that parametrium invasion (hazard ratio $=4.663$; 95\% CI: 1.496-14.533; $P=0.008$ ), stromal invasion (hazard ratio $=6.377 ; 95 \%$ CI: $1.397-29.118 ; P=0.017$ ), nerve invasion (hazard ratio $=4.044 ; \quad 95 \%$ CI: $1.514-10.804 ; \quad P=0.005), \quad$ SOX2 (hazard ratio $=4.437 ; 95 \% \mathrm{CI}: 1.276-15.428 ; P=0.019$ ), HR-HPV RISH (hazard ratio $=5.160 ; 95 \%$ CI: $1.098-$ 24.254; $P=0.038$ ), and SOX2 /HR-HPV RISH (hazard ratio $=3.597 ; 95 \% \mathrm{CI}$ : $1.085-11.928 ; P=0.036)$ may independently predict prognosis in SCNEC cases. Univariate regression analysis revealed that nerve invasion, $\mathrm{SOX} 2$, HR-HPV RISH, SOX2/P16 ${ }^{\text {INK } 4 A}$, and SOX2/HR-HPV RISH were related to DFS $(P<0.05)$. Upon multivariate regression, it was observed that nerve invasion (hazard ratio $=3.398 ; 95 \% C I: 1.606-7.190 ; P=0.001)$, SOX2 (hazard ratio $=2.530 ; 95 \% \mathrm{CI}: 1.092-5.863 ; P=0.030$ ), HR-HPV RISH (hazard ratio $=6.113$; 95\% CI: $1.406-$
26.581; $P=0.016$ ), and SOX2/HR-HPV RISH (hazard ratio $=2.880 ; 95 \%$ CI: $1.199-6.919 ; P=0.018)$ were evidently related to DFS. Additionally, in this study, we created a forest plot to display hazard ratio together with the corresponding 95\% CIs of OS and DFS, based on Cox proportional hazards regression (Fig. 2). In conformance to the above results, Kaplan-Meier curves for OS and DFS based on SOX2, P16 ${ }^{\mathrm{INK} 4 \mathrm{~A}}$, HR-HPV RISH, SOX2/P16 ${ }^{\mathrm{INK} 4 \mathrm{~A}}$, and SOX2 /HR-HPV RISH expression showed significant differences, which were verified through log-rank tests (Fig. 3). Survival analysis was also conducted, which revealed that SOX2 may be adopted to predict prognosis. Moreover, the statistical analyses indicated that SOX2 and HPV mRNA expression were associated with a series of pathological parameters related to OS (Figs. 4 and 5). Therefore, our data further suggest that SOX2, alone and in combination with HPV mRNA, is an independent prognostic marker for patients with SCNEC.

\section{Prognostic nomograms were created to predict OS and DFS}

Variables obtained based on Cox proportional analysis were then applied to build the respective OS and DFS prognostic nomograms (Fig. 6). The factors that were incorporated into the OS nomogram included stromal, parametrium, and nerve invasion, SOX2, HR-HPV RISH, and SOX2/HR-HPV RISH. Additionally, four risk factors-nerve invasion, SOX2, HR-HPV RISH, and SOX2/ HR-HPV RISH-were enrolled in the DFS nomogram. One point was assigned to the prognostic factor in the as-constructed nomograms. Then, the total points were summed up to determine outcome probability by plotting a perpendicular line to the axis of "1-, 3-, and 5-year OS/ DFS probabilities". Figure 7 shows the calibration plots used to predict OS and DFS at 1-, 3-, and 5-year intervals, which reveal the accurate predictive power.

\section{Discussion}

The present work examined the significance of SOX2, HR-HPV RISH, and clinicopathological features in SCNEC cases. The respective nomograms were constructed according to Cox hazards analysis to predict OS and DFS for SCNEC cases. Thereafter, each point was assessed for prognostic risk, and individualized posttreatment was provided. To our knowledge, the present work is the first retrospective analysis of the value of 
Table 1 Patient demographics and clinical characteristics

\begin{tabular}{|c|c|c|c|}
\hline \multirow[b]{2}{*}{ Characteristic } & \multicolumn{3}{|c|}{ SOX2 } \\
\hline & $\bar{n}$ & Low & Hig \\
\hline \multicolumn{4}{|l|}{ Age (years) } \\
\hline$<44$ & 40 & 16 & 24 \\
\hline$\geq 44$ & 48 & 15 & 33 \\
\hline \multicolumn{4}{|c|}{ HPV DNA (pg/ml) } \\
\hline$<1$ & 3 & 1 & 2 \\
\hline$\geq 1$ & 56 & 19 & 37 \\
\hline \multicolumn{4}{|l|}{ FIGO stage } \\
\hline$\leq \| \mathrm{A}$ & 79 & 26 & 53 \\
\hline$\geq \| \mathrm{B}$ & 9 & 5 & 4 \\
\hline \multicolumn{4}{|c|}{ Pre-operative Chemotherapy } \\
\hline No & 56 & 16 & 40 \\
\hline Yes & 32 & 15 & 17 \\
\hline
\end{tabular}

Post-operative Chemotherapy

$$
\begin{aligned}
& \text { No } \\
& \text { Yes }
\end{aligned}
$$

Post-operative Radiotherapy

$$
\begin{aligned}
& \text { No } \\
& \text { Yes }
\end{aligned}
$$

Pathological type

SCNEC -alone

SCNEC -mix

Tumor size $(\mathrm{cm})$

$$
\begin{aligned}
& <2 \\
& 2-4 \\
& \geq 4
\end{aligned}
$$

Stromal invasion

$$
\begin{aligned}
& <1 / 2 \\
& \geq 1 / 2
\end{aligned}
$$

Endometrial invasion

$$
\text { No }
$$$$
\text { Yes }
$$

\section{Parametrium invasion}

$\begin{array}{llll}\text { No } & 78 & 27 & 51 \\ \text { Yes } & 10 & 4 & 6\end{array}$

CIN

$\begin{array}{llll}\text { No } & 73 & 26 & 47 \\ \text { Yes } & 15 & 5 & 10\end{array}$

LNM

No
Yes

Nerve invasion

$$
\text { No }
$$$$
\text { Yes }
$$

LVI

$\begin{array}{lll}4 & 1 & 3 \\ 84 & 30 & 54\end{array}$

$\begin{array}{lll}33 & 15 & 18 \\ 55 & 16 & 39\end{array}$

$\begin{array}{lll}66 & 24 & 42\end{array}$

$\begin{array}{lll}22 & 7 & 15\end{array}$

$11 \quad 6 \quad 5$

$\begin{array}{lll}40 & 13 & 27\end{array}$

$\begin{array}{lll}37 & 12 \quad 25\end{array}$

$\begin{array}{lll}28 & 10 \quad 18\end{array}$

$\begin{array}{lll}60 & 21 \quad 39\end{array}$

$\begin{array}{lll}79 & 26 & 53\end{array}$

$\begin{array}{lll}79 & 26 & 53 \\ 9 & 5 & 4\end{array}$

$\begin{array}{lll}52 & 16 \quad 36\end{array}$

$\begin{array}{lll}36 & 15 & 21\end{array}$

$\frac{P}{0.392}$

P16 INK4A

n Neg.

$\begin{array}{ll}\text { Pos. } & \boldsymbol{P} \\ & 0.364\end{array}$

HR-HPV RISH

\begin{tabular}{llll}
\hline n & Neg. & Pos. & $P$ \\
\hline
\end{tabular}

\subsection{3}

$\begin{array}{lll}40 & 4 & 36\end{array}$

$\begin{array}{lll}48 & 8 & 40\end{array}$

0.983

0.178

$\begin{array}{lll}3 & 0 & 3 \\ 56 & 7 & 49\end{array}$

178

79

0.084

$\begin{array}{lll}79 & 11 & 68 \\ 9 & 1 & 8\end{array}$

.

$\begin{array}{lll}56 & 7 & 49 \\ 32 & 5 & 27\end{array}$

0.661

$\begin{array}{cccc}40 & 8 & 32 \\ & 48 & 7 & 41 \\ 0.514 & & & \\ 3 & 2 & 1 \\ 56 & 9 & 47\end{array}$

0.816

0.028

$\begin{array}{cccc} & 79 & 11 & 68 \\ & 9 & 4 & 5 \\ 0.681 & & & \\ & 56 & 5 & 51 \\ & 32 & 10 & 22\end{array}$

0.416

$\begin{array}{lll}4 & 0 & 4 \\ 84 & 12 & 72\end{array}$

0.120

$\begin{array}{cccc} & 4 & 0 & 4 \\ & 84 & 15 & 69 \\ 0.109 & & & \\ & 33 & 6 & 27 \\ 55 & 9 & 46\end{array}$

0.473

0.014

0.699

$\begin{array}{lll}33 & 2 & 31 \\ 55 & 10 & 45\end{array}$

0.358

$\begin{array}{lll}66 & 10 & 56 \\ 22 & 2 & 20\end{array}$

$11 \quad 3 \quad 8$

0.948

$\begin{array}{lll}40 & 7 & 33\end{array}$

$\begin{array}{lll}37 & 2 & 35\end{array}$

25

$\begin{array}{lll}28 & 2 & 26\end{array}$

0.178

$\begin{array}{lll}60 & 10 & 50\end{array}$

0.737

$$
\begin{array}{lll}
79 & 11 & 68 \\
9 & 1 & 8
\end{array}
$$

$\begin{array}{lll}78 & 12 \quad 66\end{array}$

0.866

$$
\begin{array}{lll}
78 & 12 & 66 \\
10 & 0 & 10
\end{array}
$$$$
\begin{array}{lll}
73 & 10 & 63 \\
15 & 2 & 13
\end{array}
$$

0.293

0.835

$\begin{array}{lll}52 & 8 & 44\end{array}$

$$
\begin{array}{lll}
52 & 8 & 44 \\
36 & 4 & 32
\end{array}
$$

0.112

0.896

0.225

0.170

0.816

$\begin{array}{lll}28 & 3 & 25 \\ 60 & 12 & 48\end{array}$

0.826

0.007

$\begin{array}{lll}79 & 12 & 67\end{array}$

0.182

0.792

0.970

0.566

$$
\begin{array}{lll}
73 & 14 & 59 \\
15 & 1 & 14
\end{array}
$$

$\begin{array}{lll}52 & 7 & 45\end{array}$

0.921

0.176

0.973 $\begin{array}{lll}67 & 24 & 43\end{array}$

$\begin{array}{lll}21 & 7 & 14\end{array}$

0.023

$\begin{array}{lll}67 & 9 & 58 \\ 21 & 3 & 15\end{array}$

$\begin{array}{lll}29 & 15 & 14\end{array}$

$29 \quad 5 \quad 24$ 
Table 1 Patient demographics and clinical characteristics (Continued)

\begin{tabular}{|c|c|c|c|c|c|c|c|c|c|c|c|c|}
\hline \multirow[b]{2}{*}{ Characteristic } & \multicolumn{4}{|c|}{ SOX2 } & \multicolumn{4}{|c|}{ P16 ${ }^{\text {INK4A }}$} & \multicolumn{4}{|c|}{ HR-HPV RISH } \\
\hline & $n$ & Low & High & $P$ & $n$ & Neg. & Pos. & $P$ & $n$ & Neg. & Pos. & $P$ \\
\hline Yes & 59 & 16 & 43 & & 59 & 6 & 53 & & 59 & 10 & 49 & \\
\hline Relapse & & & & 0.023 & & & & 0.297 & & & & 0.027 \\
\hline No & 54 & 24 & 30 & & 54 & 9 & 45 & & 54 & 13 & 41 & \\
\hline Yes & 34 & 7 & 27 & & 34 & 3 & 31 & & 34 & 2 & 32 & \\
\hline $\mathrm{N}$-marker & & & & 0.900 & & & & 0.069 & & & & 0.021 \\
\hline$\leq 2+$ & 9 & 3 & 6 & & 9 & 3 & 6 & & 9 & 4 & 5 & \\
\hline$>2+$ & 79 & 28 & 51 & & 79 & 9 & 70 & & 79 & 11 & 68 & \\
\hline MMR & & & & 0.737 & & & & 0.182 & & & & 0.792 \\
\hline pMMR & 78 & 27 & 51 & & 78 & 12 & 66 & & 78 & 13 & 65 & \\
\hline $\mathrm{dMMR}$ & 10 & 4 & 6 & & 10 & 0 & 10 & & 10 & 2 & 8 & \\
\hline Ki67(\%) & & & & 0.105 & & & & 0.005 & & & & 0.154 \\
\hline$<60$ & 13 & 2 & 11 & & 13 & 5 & 8 & & 13 & 4 & 9 & \\
\hline$\geq 60$ & 75 & 29 & 46 & & 75 & 7 & 68 & & 75 & 11 & 64 & \\
\hline
\end{tabular}

CIN Cervical Intraepithelial Neoplasia, LNM Lymph Node Metastasis, LVI Lymphatic Vessel Invasion, N-marker Neuroendocrine-marker, MMR Mismatch Repair

Table 2 Univariate and multivariate Cox proportional hazards regression analysis for OS

\begin{tabular}{|c|c|c|c|c|}
\hline \multirow[t]{2}{*}{ Variables } & \multicolumn{2}{|l|}{ Univariate } & \multicolumn{2}{|l|}{ Multivariate } \\
\hline & $\mathrm{HR}(95 \% \mathrm{Cl})$ & $P$ value & $\mathrm{HR}(95 \% \mathrm{Cl})$ & $P$ value \\
\hline Age (years) (<44 vs. $\geq 44)$ & $1.253(0.632-2.482)$ & 0.518 & & \\
\hline HPV DNA (pg/ml) $(<1$ vs. $\geq 1)$ & $0.240(0.071-0.813)$ & 0.022 & & \\
\hline FIGO stage ( $\leq \| \mathrm{A}$ vs. $\geq \| \mathrm{B})$ & $2.373(0.914-6.158)$ & 0.076 & & \\
\hline Pathological type (SCNEC -alone vs. SCNEC -mix) & $1.448(0.661-3.174)$ & 0.355 & & \\
\hline Pre-operative Chemotherapy (No vs. Yes) & $1.148(0.721-2.787)$ & 0.312 & & \\
\hline Post-operative Chemotherapy (No vs. Yes) & $0.514(0.122-2.161)$ & 0.364 & & \\
\hline Post-operative Radiotherapy (No vs. Yes) & $1.558(0.726-3.342)$ & 0.255 & & \\
\hline Tumor size $(\mathrm{cm})(<2$ vs. $2-4$ vs. $\geq 4)$ & $1.528(0.890-2.624)$ & 0.124 & & \\
\hline Stromal invasion (< 1/2 vs. $\geq 1 / 2)$ & $2.481(1.026-5.997)$ & 0.044 & $6.377(1.397-29.118)$ & 0.017 \\
\hline Endometrial invasion (No vs. Yes) & $1.841(0.711-4.769)$ & 0.209 & & \\
\hline Parametrium invasion (No vs. Yes) & $2.946(1.276-6.802)$ & 0.011 & $4.663(1.496-14.533)$ & 0.008 \\
\hline CIN (No vs. Yes) & $0.667(0.235-1.898)$ & 0.448 & & \\
\hline LNM (No vs. Yes) & $1.697(0.865-3.326)$ & 0.124 & & \\
\hline Nerve invasion (No vs. Yes) & $3.630(1.814-7.264)$ & 0.000 & $4.044(1.514-10.804)$ & 0.005 \\
\hline LVI (No vs. Yes) & $2.150(0.964-4.797)$ & 0.061 & & \\
\hline $\mathrm{N}$-marker $(\leq 2+$ vs. $>2+)$ & $1.777(0.542-5.829)$ & 0.343 & & \\
\hline MMR (pMMR vs. dMMR) & $0.039(0.001-2.816)$ & 0.138 & & \\
\hline Ki67 (<60 vs. $\geq 60 \%)$ & $1.485(0.522-4.223)$ & 0.458 & & \\
\hline SOX2 (Low vs. High) & $2.658(1.154-6.125)$ & 0.022 & $4.437(1.276-15.428)$ & 0.019 \\
\hline P16 $6^{\text {INK4A }}(-$ Vs. + ) & $2.646(0.806-8.690)$ & 0.109 & & \\
\hline HR-HPV RISH (- vs. +) & $3.195(0.961-10.625)$ & 0.048 & $5.160(1.098-24.254)$ & 0.038 \\
\hline SOX2/ P16 $6^{\text {INK4A }}$ (Al vs. All vs. Alll) & $2.457(1.267-4.766)$ & 0.008 & $1.593(0.481-5.274)$ & 0.446 \\
\hline SOX2/ HR-HPV RISH (BI vs. Bll vs. BIII) & $3.462(1.655-7.242)$ & 0.001 & $3.597(1.085-11.928)$ & 0.036 \\
\hline
\end{tabular}

CIN Cervical Intraepithelial Neoplasia, LNM Lymph Node Metastasis, LVI Lymphatic Vessel Invasion, $N$-marker Neuroendocrine-marker, MMR Mismatch Repair, $A$ I

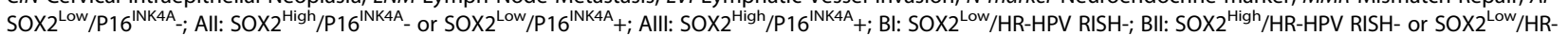
HPV RISH+; BIII: SOX2 $2^{\text {High }} / \mathrm{HR}-\mathrm{HPV}$ RISH+ 
Table 3 Univariate and multivariate Cox proportional hazards regression analysis for DFS

\begin{tabular}{|c|c|c|c|c|}
\hline \multirow[t]{2}{*}{ Variables } & \multicolumn{2}{|l|}{ Univariate } & \multicolumn{2}{|l|}{ Multivariate } \\
\hline & $\mathrm{HR}(95 \% \mathrm{Cl})$ & $P$ value & $\mathrm{HR}(95 \% \mathrm{Cl})$ & $P$ value \\
\hline Age (years) (<44 vs. $\geq 44)$ & $1.241(0.626-2.459)$ & 0.536 & & \\
\hline HPV DNA (pg/ml) $(<1$ vs. $\geq 1)$ & $0.659(0.087-4.978)$ & 0.686 & & \\
\hline FIGO stage ( $\leq \| \mathrm{A}$ vs. $\geq \| \mathrm{B})$ & $1.797(0.630-5.128)$ & 0.273 & & \\
\hline Pathological type (SCNEC -alone vs. SCNEC -mix) & $1.455(0.685-3.092)$ & 0.330 & & \\
\hline Pre-operative Chemotherapy (No vs. Yes) & $0.841(0.408-1.733)$ & 0.638 & & \\
\hline Post-operative Chemotherapy (No vs. Yes) & $0.372(0.113-1.224)$ & 0.104 & & \\
\hline Post-operative Radiotherapy (No vs. Yes) & $0.790(0.398-1.565)$ & 0.499 & & \\
\hline Tumor size $(\mathrm{cm})(<2$ vs. $2-4$ vs. $\geq 4)$ & $1.132(0.675-1.899)$ & 0.637 & & \\
\hline Stromal invasion (< 1/2 vs. $\geq 1 / 2)$ & $1.382(0.660-2.892)$ & 0.391 & & \\
\hline Endometrial invasion (No vs. Yes) & $1.136(0.347-3.722)$ & 0.833 & & \\
\hline Parametrium invasion (No vs. Yes) & $2.359(0.910-6.119)$ & 0.077 & & \\
\hline CIN (No vs. Yes) & $1.171(0.509-2.696)$ & 0.711 & & \\
\hline LNM (No vs. Yes) & $1.071(0.536-2.141)$ & 0.845 & & \\
\hline Nerve invasion (No vs. Yes) & $2.707(1.310-5.594)$ & 0.007 & $3.398(1.606-7.190)$ & 0.001 \\
\hline LVI (No vs. Yes) & $2.061(0.928-4.576)$ & 0.076 & & \\
\hline N-marker $(\leq 2+$ vs. $>2+)$ & $1.472(0.449-4.828)$ & 0.523 & & \\
\hline MMR (pMMR vs. dMMR) & $0.039(0.001-2.416)$ & 0.123 & & \\
\hline Ki67 (<60 vs. $\geq 60 \%)$ & $3.244(0.777-13.551)$ & 0.107 & & \\
\hline SOX2 (Low vs. High) & $2.401(1.044-5.524)$ & 0.039 & $2.530(1.092-5.863)$ & 0.030 \\
\hline P16 $6^{\text {INK4A }}(-$ Vs. + ) & $2.246(0.685-7.366)$ & 0.182 & & \\
\hline HR-HPV RISH (- vs. +) & $4.309(1.019-19.208)$ & 0.047 & $6.113(1.406-26.581)$ & 0.016 \\
\hline SOX2/ P16 INK4A (Al vs. All vs. Alll) & $2.123(1.108-4.067)$ & 0.023 & $1.239(0.564-2.721)$ & 0.593 \\
\hline SOX2/ HR-HPV RISH (BI vs. BII vs. BIII) & $3.220(1.532-6.771)$ & 0.002 & $2.880(1.199-6.919)$ & 0.018 \\
\hline
\end{tabular}

CIN Cervical Intraepithelial Neoplasia, LNM Lymph Node Metastasis, LVI Lymphatic Vessel Invasion, $N$-marker Neuroendocrine-marker, MMR Mismatch Repair, $A$ I

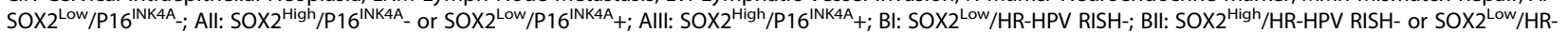
HPV RISH+; Blll: SOX2 ${ }^{\text {High }} /$ HR-HPV RISH+

SOX2 and HR-HPV RISH in predicting the prognosis for SCNEC.

The dysregulated OCT4/SOX2 complex has been detected in various human malignant tumors [27], and thus, SOX2 plays a critical role in cancer development [7]. Overexpression of SOX2 has been detected in human cancers, and therefore, it may serve as an oncogene [28]. Additionally, previous studies have examined the effect of SOX2 levels on small cell neuroendocrine carcinomas (NECs) in certain organs, and found that SOX2 possibly plays a vital role in small cell NEC progression in the endometrium, esophagus, and lung [29-31]. Nonetheless, little research has focused on SOX2 expression and its clinical value in cancer. In the present study, SOX2 independently predicted the poor prognosis of SCNEC, similar to the results of prior studied [32]. Hence, SOX2 plays an important role in SCNEC development.

The role of HPV in the etiology of SCNEC is well established, and HR-HPV can be detected in the majority of the patients [33]. The presence of $\mathrm{P} 16^{\mathrm{INK} 4 \mathrm{a}}$ / Ki-67 can serve as a candidate marker for HR-HPV infection in HPV-associated endocervical neoplasia [34, $35]$. However, the scoring system of $16^{\mathrm{INK} 4 \mathrm{a}}$ is currently controversial, often leading to a misinterpretation of the staining results [36], and the diagnostic value of Ki-67 in SCNEC remains ambiguous. HR-HPV RISH is a robust technique for HR-HPV diagnosis [37, 38] and detects the full-length or fragments of E6 and E7 transcripts using cascade signal amplification [38]. Studies have shown that persistent infection with HR-HPVs results in integration of the viral genome fragments into the host chromosomes, thus facilitating the transcription of typespecific E6/7 genes and protein overexpression, which eventually leads to the activation of the downstream carcinogenetic signaling pathways [37]. Recent studies have shown that HR-HPV RISH effectively diagnoses endocervical adenocarcinoma and endocervical glandular neoplasia [39, 40]. Therefore, a high specificity of HRHPV RISH for HPV-driven cervical neoplasia is 


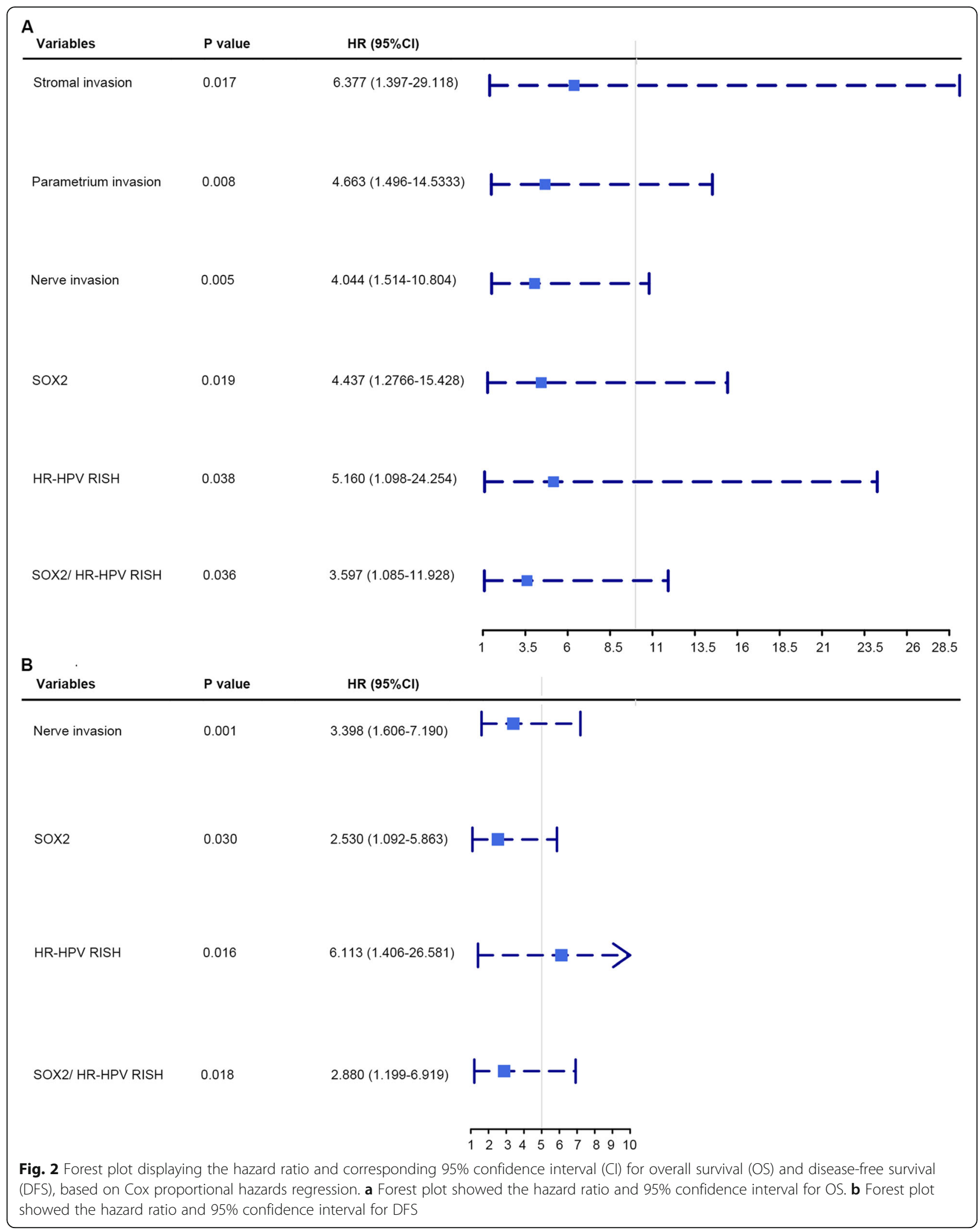




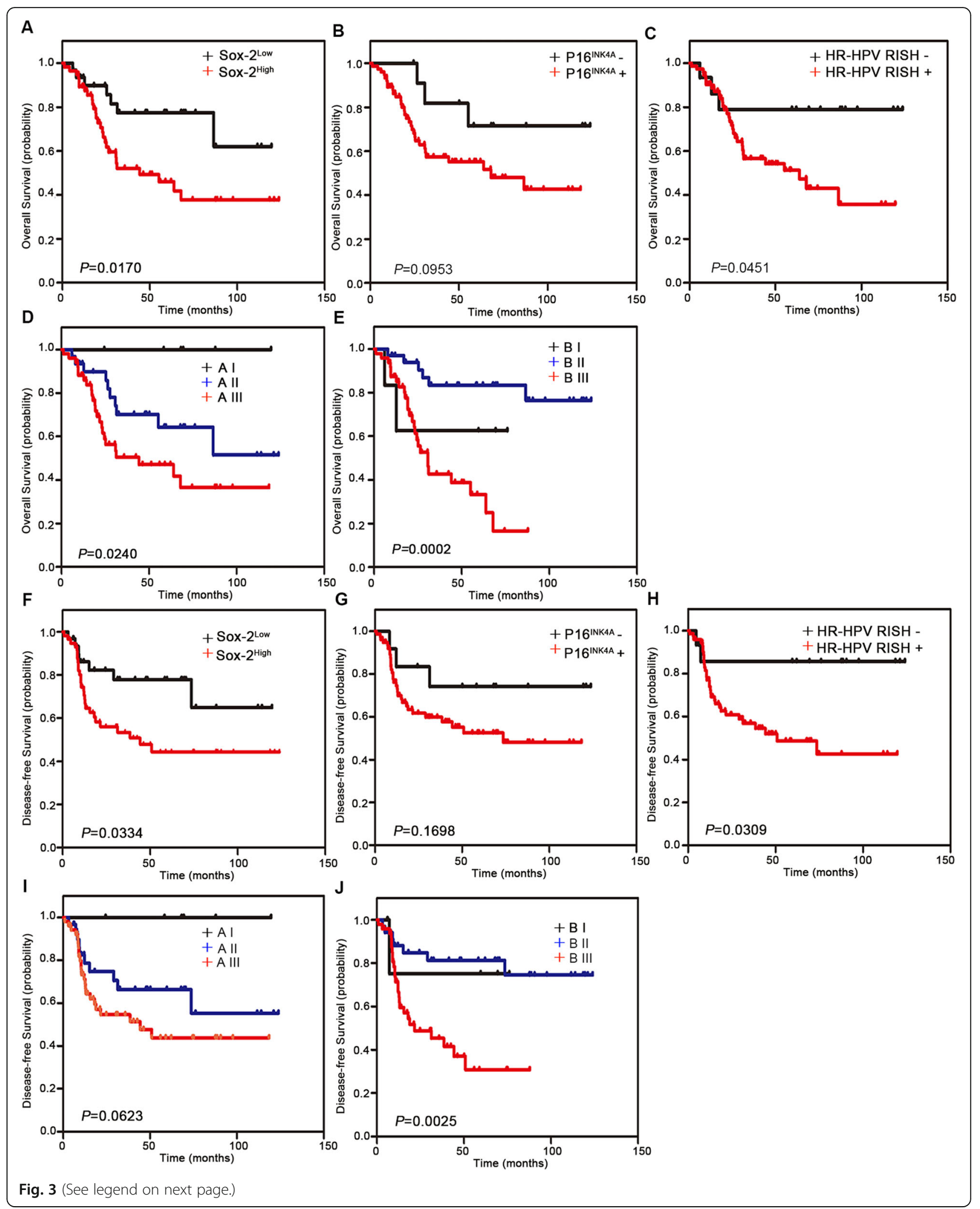


(See figure on previous page.)

Fig. 3 Kaplan-Meier survival curves for OS and DFS of small cell neuroendocrine carcinoma of the uterine cervix (SCNEC) cases according to SOX2, P16 $6^{\text {INK4A }}$, and high-risk-human papilloma virus (HR-HPV) RISH expression. a-c OS according to SOX2, P16 $6^{\text {INK4A }}$, and HR-HPV RISH expression status in patients with SCNEC. $\mathbf{d}$ OS according to a combination of SOX2/P16 ${ }^{\text {INK4A }}$ co-expression. Group Al: SOX2 $2^{\text {Low }} /$ P $16^{\text {INK4A }}$-; Group All: SOX2 $2^{\text {High }} / \mathrm{P} 16^{\text {INK4A }}$ - or SOX2 $2^{\text {Low }} / \mathrm{P} 16^{\text {INK4A }}+$; Group Alll: SOX2 $2^{\text {High }} / \mathrm{P} 16^{\text {INK4A }}+$. e OS according to a combination of SOX2- IHC/HR-HPV RISH CO-

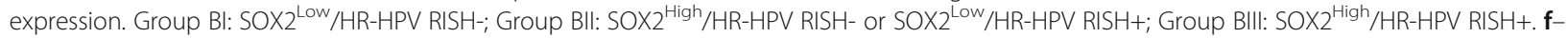
h DFS according to SOX2, P16 $6^{\text {INK4A }}$, and HR-HPV RISH expression status in patients with SCNEC. $\mathbf{i}$ DFS according to a combination of SOX2/

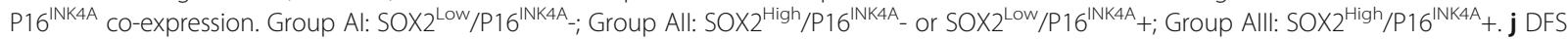
according to a combination of SOX2- IHC/HR-HPV RISH co-expression. Group BI: SOX2 ${ }^{\text {Low }} / \mathrm{HR}$-HPV RISH-; Group BII: SOX2 ${ }^{\mathrm{High}} / \mathrm{HR}-\mathrm{HPV}$ RISH- or SOX2 ${ }^{\text {Low }} /$ HR-HPV RISH+; Group BIII: SOX2 $2^{\text {High }} /$ HR-HPV RISH+
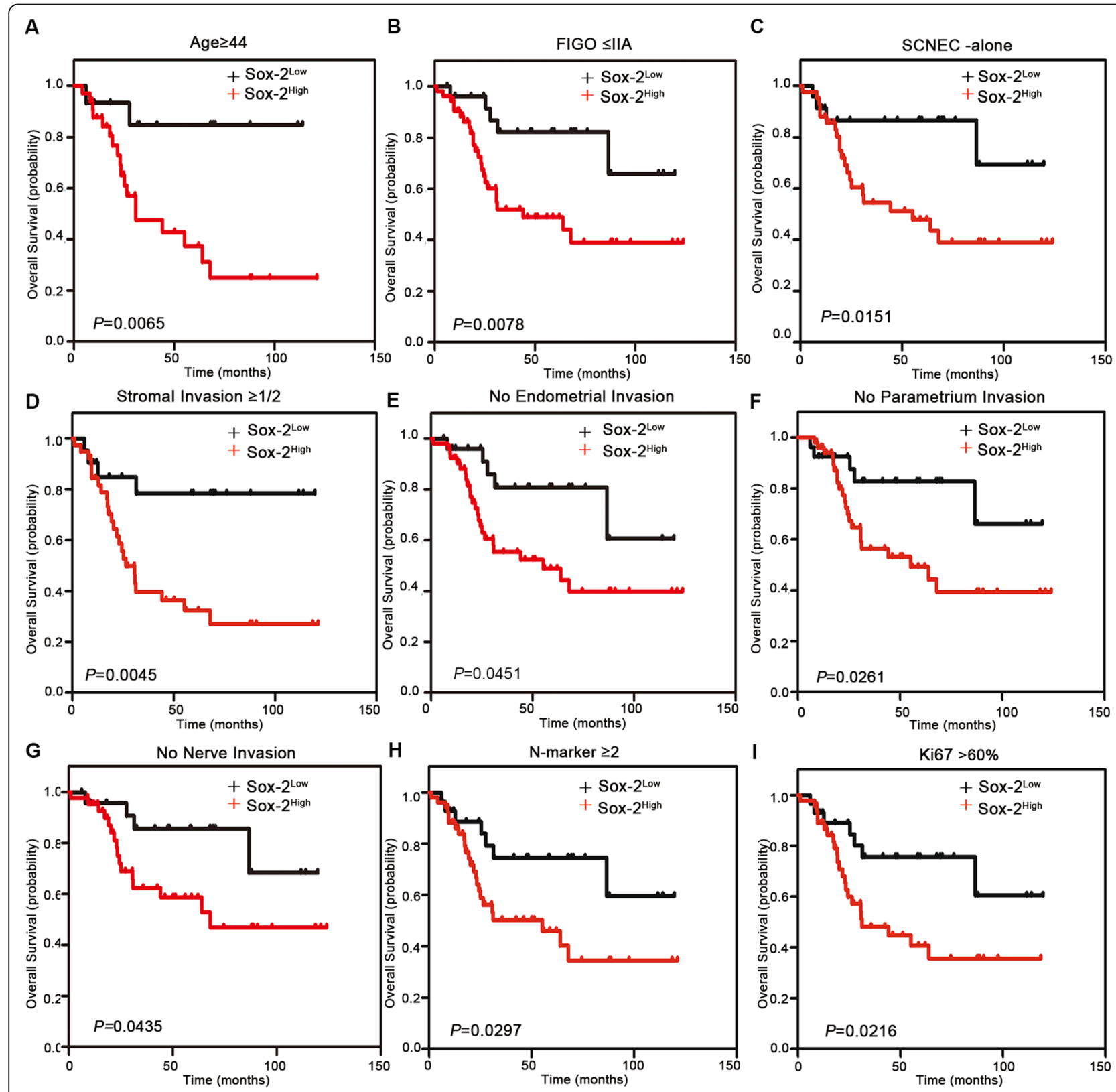

Fig. 4 Stratified analysis of the OS-related SOX2 level. a-i Relationship of the SOX2 level with OS in specific groups 


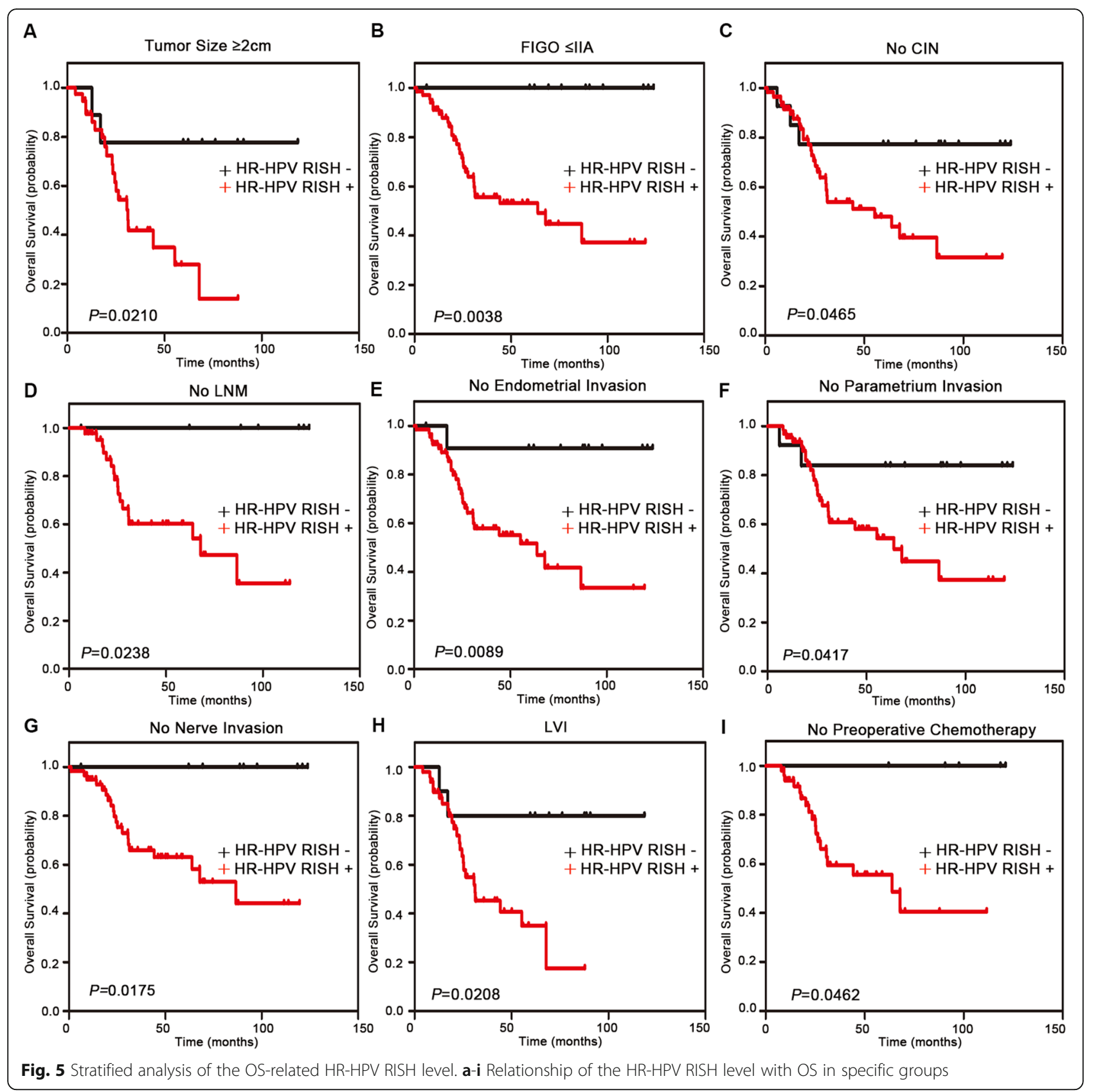

expected. In our study, HR-HPV RISH showed higher sensitivity and specificity for SCNEC, compared to P16 ${ }^{\mathrm{INK} 4 \mathrm{a}}$ and Ki-67 IHC. Multivariate analysis demonstrated that SOX2/HR-HPV RISH co-expression served as an independent factor in predicting the OS and DFS in SCNEC cases. Further studies, using larger cohorts, should be conducted to validate our findings.

Consistent with our results, SOX2 was proven to be a potential marker to predict overall survival and recurrence in p16+ oropharyngeal cancer [41]. Recent studies have shown that SOX2 was related to HPV infection. Interestingly, HPV infection drives switches in SOX2 expression in the transformation zone in the uterine cervix [15], and SOX2 locus amplification was related with HPV mRNA positivity in vulvar carcinoma [14]. Furthermore, SOX2 was reported to be regulator of HPV16 at the transcriptional level in cervical squamous cell carcinoma [42]. That may explain the possible molecular mechanism between them. In our study, both SOX2 and HR-HPV RISH were independent prognostic factors for SCNEC. Unfortunately, there is no significant difference between the expression of SOX2 and HR-HPV RISH in the correlation analysis, which may also be related to the sample size. Therefore, the possible molecular mechanism between 


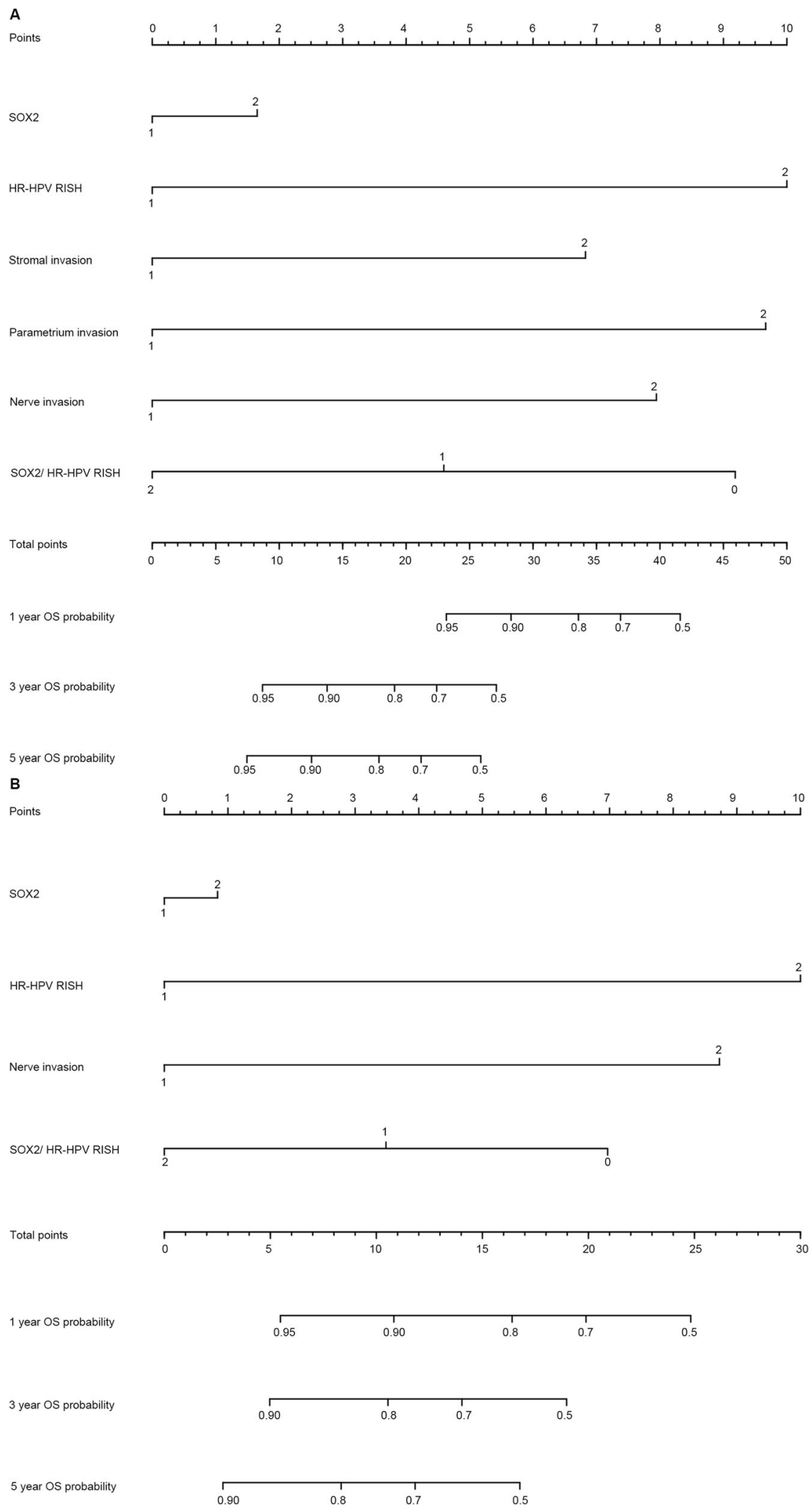

Fig. 6 Nomograms created for predicting 1-, 3-, and 5-year OS and DFS for SCNEC. a Nomogram created for predicting 1-, 3-, and 5-year OS for SCNEC. b Nomogram created for predicting 1-, 3-, and 5-year DFS for SCNEC 


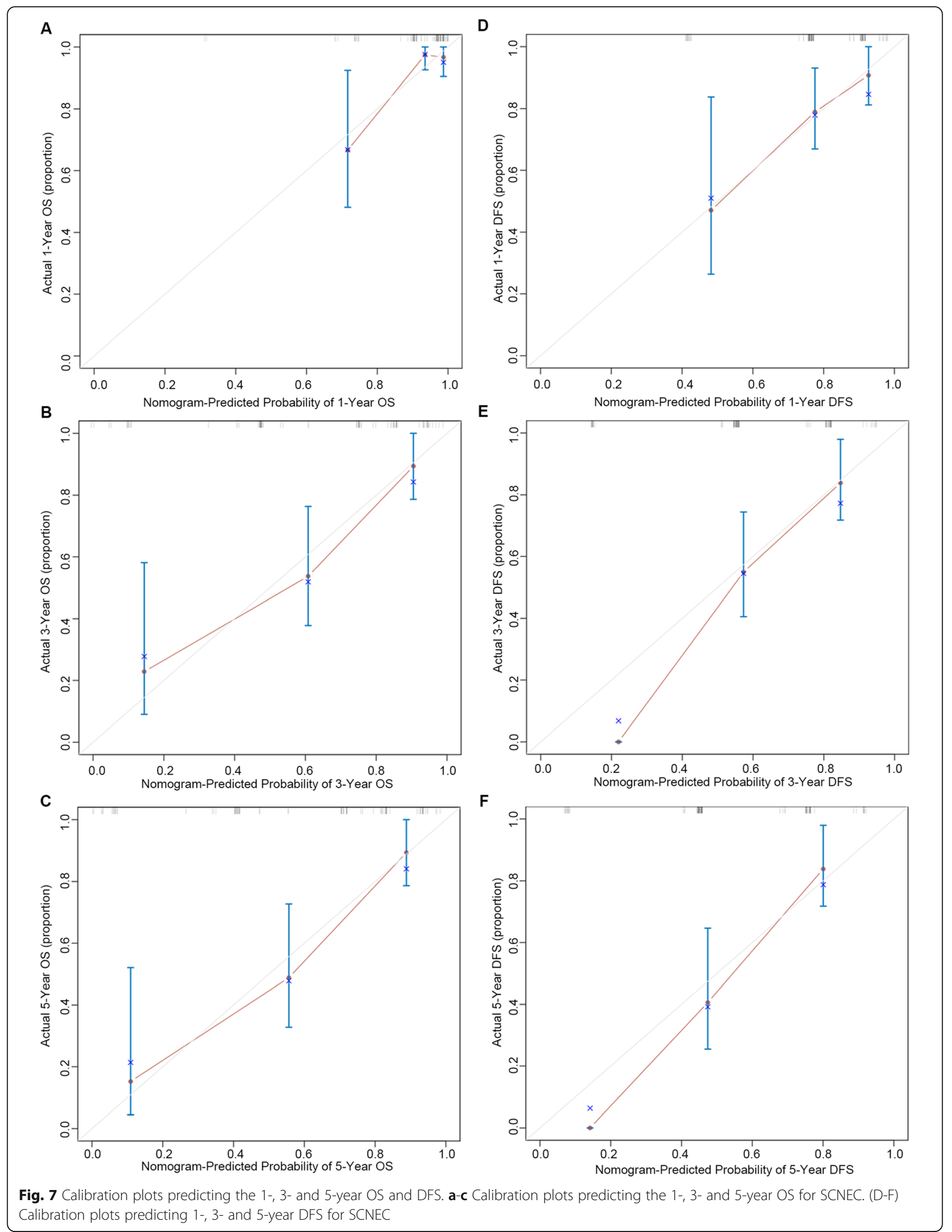


SOX2 and HPV infection in SCNEC remains to be further studied.

There were several limitations to this study. First, its retrospective nature may lead to inevitable selection bias. Second, this study was conducted with a small sample size from a single center. Third, the present work only focused on the significance of SOX2 and HR-HPV RISH in predicting prognosis, while other prognostic factors, such as molecular biomarkers or inflammatory prognostic markers, were not included. Therefore, the results of this work should be further validated in multi-center studies with a larger sample size.

\section{Supplementary Information}

The online version contains supplementary material available at https://doi. org/10.1186/s12885-021-08059-1.

\section{Additional file 1.}

\section{Acknowledgements}

Not applicable.

\section{Authors' contributions}

Conception and design: Rong-Zhen Luo and Li-Li Liu. Performing experiments: Shi-Wen Zhang, Xiao-Ying Sun and Xia Yang. Drafting of the article: Shi-Wen Zhang and Li-Li Liu. Acquisition and interpretation of data: Hai-Xia Yang, Si-Ping Xiong. Review, editing and approval of the manuscript: all authors.

\section{Funding}

The National Natural Science Foundation of China (No. 82072853). The Natural Science Foundation of Guangdong Province (No.2021A1515010688).

\section{Availability of data and materials}

All data generated or analyzed during this study are included in this article [and its supplementary information files].

\section{Declarations}

\section{Ethics approval and consent to participate}

We confirm that we have passed the ethics committee of Sun Yat-sen University Cancer Center and all methods were carried out in accordance with the guidelines and regulations. All biological samples were obtained with patients' written informed consent.

\section{Consent for publication}

Not applicable.

\section{Competing interests}

The authors declare that they have no competing interests.

\section{Author details}

${ }^{1}$ Department of Pathology, Sun Yat-sen University Cancer Center, Guangzhou 510060, China. ${ }^{2}$ Department of Pathology, the Eighth Affiliated Hospital, Sun Yat-sen University, Shenzhen 51800, China. ${ }^{3}$ Department of Gynecological Oncology, Sun Yat-sen University Cancer Center, Guangzhou 510060, China.

Received: 28 December 2020 Accepted: 9 March 2021

Published online: 31 March 2021

\section{References}

1. Wharton D, Kim E, Pagan J, Small W Jr, Jaboin J, Ayala-Peacock D. Patterns of care and outcomes for Small cell carcinoma of the cervix: a National Retrospective Analysis of 542 cases. Adv Radiat Oncol. 2020;5(3):412-8. https://doi.org/10.1016/j.adro.2019.08.008.
2. Cohen JG, Kapp DS, Shin JY, Urban R, Sherman AE, Chen LM, Osann K, Chan JK. Small cell carcinoma of the cervix: treatment and survival outcomes of 188 patients. Am J Obstetrics Gynecol. 2010;203(4):347 e341-346.

3. Chen J, Macdonald OK, Gaffney DK. Incidence, mortality, and prognostic factors of small cell carcinoma of the cervix. Obstet Gynecol. 2008;111(6): 1394-402. https://doi.org/10.1097/AOG.0b013e318173570b.

4. Dongol S, Tai Y, Shao Y, Jiang J, Kong B. A retrospective clinicopathological analysis of small-cell carcinoma of the uterine cervix. Mol Clin Oncol. 2014. 2(1):71-5. https://doi.org/10.3892/mco.2013.193.

5. Lorusso D, Petrelli F, Coinu A, Raspagliesi F, Barni S. A systematic review comparing cisplatin and carboplatin plus paclitaxel-based chemotherapy for recurrent or metastatic cervical cancer. Gynecol Oncol. 2014;133(1):117-23. https://doi.org/10.1016/j.ygyno.2014.01.042.

6. Weina K, Utikal J. SOX2 and cancer: current research and its implications in the clinic. Clin Transl Med. 2014:3:19.

7. Novak D, Hüser L, Elton JJ, Umansky V, Altevogt P, Utikal J. SOX2 in development and cancer biology. Semin Cancer Biol. 2020;67:74-82.

8. Annovazzi L, Mellai M, Caldera V, Valente G, Schiffer D. SOX2 expression and amplification in gliomas and glioma cell lines. Cancer Genomics Proteomics. 2011;8(3):139-47.

9. Gure AO, Stockert E, Scanlan MJ, Keresztes RS, Jager D, Altorki NK, Old LJ, Chen YT. Serological identification of embryonic neural proteins as highly immunogenic tumor antigens in small cell lung cancer. Proc Natl Acad Sci U S A. 2000;97(8):4198-203. https://doi.org/10.1073/ pnas.97.8.4198

10. Rudin CM, Durinck S, Stawiski EW, Poirier JT, Modrusan Z, Shames DS, Bergbower EA, Guan Y, Shin J, Guillory J, Rivers CS, Foo CK, Bhatt D, Stinson J, Gnad F, Haverty PM, Gentleman R, Chaudhuri S, Janakiraman V, Jaiswal BS, Parikh C, Yuan W, Zhang Z, Koeppen H, Wu TD, Stern HM, Yauch RL, Huffman KE, Paskulin DD, Illei PB, Varella-Garcia M, Gazdar AF, de Sauvage FJ, Bourgon R, Minna JD, Brock MV, Seshagiri S. Comprehensive genomic analysis identifies SOX2 as a frequently amplified gene in small-cell lung cancer. Nat Genet. 2012;44(10):1111-6. https://doi.org/10.1038/ng.2405

11. Chang X, Zhang J, Huang C, Pang X, Luo Q, Zhang H, Zhang S. Sexdetermining region Y-related high mobility group box (SOX)-2 is overexpressed in cervical squamous cell carcinoma and contributes cervical cancer cell migration and invasion in vitro. Tumour Biol. 2015;36(10):772533. https://doi.org/10.1007/s13277-015-3450-y.

12. Wolsky RJ, Harbour LN, Mirza KM, Montag AG, Gwin K. The stem cellassociated transcription factor SOX2 as a diagnostic marker of high-grade squamous intraepithelial lesion of the uterine cervix in comparison with p16 and Ki-67. Appl Immunohistochem Mol Morphol. 2018;26(6):403-10. https://doi.org/10.1097/PAl.0000000000000434.

13. Stewart CJR, Crook ML. Podoplanin and SOX2 expression in CIN 3-like squamous cell carcinoma of the cervix. Int J Gynecol Pathol. 2018;37(1):5967. https://doi.org/10.1097/PGP.0000000000000383.

14. Gut A, Moch $H$, Choschzick M. SOX2 gene amplification and overexpression is linked to HPV-positive vulvar carcinomas. Int J Gynecol Pathol. 2018;37(1): 68-73. https://doi.org/10.1097/PGP.0000000000000388.

15. Moshi JM, Hoogduin KJ, Ummelen M, Henfling MER, van Engeland M, Wouters KAD, Stoop H, Demers I, Looijenga LHJ, Ramaekers FCS, et al. Switches of SOX17 and SOX2 expression in the development of squamous metaplasia and squamous intraepithelial lesions of the uterine cervix. Cancer Med. 2020;9(17):6330-43. https://doi.org/10.1002/cam4.3201.

16. Small W Jr, Bacon MA, Bajaj A, Chuang LT, Fisher BJ, Harkenrider MM, Jhingran A, Kitchener HC, Mileshkin LR, Viswanathan AN, Gaffney DK. Cervical cancer: a global health crisis. Cancer. 2017;123(13):2404-12. https://doi.org/10.1002/cncr.30667.

17. Atienza-Amores M, Guerini-Rocco E, Soslow RA, Park KJ, Weigelt B. Small cell carcinoma of the gynecologic tract: a multifaceted spectrum of lesions. Gynecol Oncol. 2014;134(2):410-8. https://doi.org/10.1016/j. ygyno.2014.05.017.

18. Satoh T, Takei Y, Treilleux I, Devouassoux-Shisheboran M, Ledermann J, Viswanathan AN, Mahner S, Provencher DM, Mileshkin L, Avall-Lundqvist E, et al. Gynecologic Cancer InterGroup (GCIG) consensus review for small cell carcinoma of the cervix. Int J Gynecol Cancer. 2014;24(9 Suppl 3):S102-8. https://doi.org/10.1097/IGC.0000000000000262.

19. Carow K, Read C, Hafner N, Runnebaum IB, Corner A, Durst M. A comparative study of digital PCR and real-time GPCR for the detection and quantification of HPV mRNA in sentinel lymph nodes of cervical cancer 
patients. BMC Res Notes. 2017;10(1):532. https://doi.org/10.1186/s13104-01 7-2846-8.

20. Ren C, Zhu Y, Yang L, Zhang X, Liu L, Wang Z, Jiang D. Prognostic and diagnostic validity of p16/Ki-67, HPV E6/E7 mRNA, and HPV DNA in women with ASCUS: a follow-up study. Virol J. 2019;16(1):143. https://doi.org/10.11 86/s12985-019-1251-4.

21. Pruski D, Millert-Kalinska S, Lewek A, Kedzia W. Sensitivity and specificity of HR HPV E6/E7 mRNA test in detecting cervical squamous intraepithelial lesion and cervical cancer. Ginekol Pol. 2019;90(2):66-71. https://doi.org/10. 5603/GP.2019.0011.

22. Hodgson A, Howitt BE, Park KJ, Lindeman N, Nucci MR, Parra-Herran C. Genomic characterization of HPV-related and gastric-type Endocervical adenocarcinoma: correlation with subtype and clinical behavior. Int J Gynecol Pathol. 2020;39(6):578-86. https://doi.org/10.1097/PGP. 0000000000000665.

23. Bakheet AMH, Zhao C, Chen JN, Zhang JY, Huang JT, Du Y, Gong LP, Bi YH, Shao CK. Improving pathological early diagnosis and differential biomarker value for hepatocellular carcinoma via RNAscope technology. Hepatol Int. 2020;14(1):96-104. https://doi.org/10.1007/s12072-019-10006-z.

24. Anderson CM, Zhang B, Miller M, Butko E, Wu X, Laver T, Kernag C, Kim J, Luo Y, Lamparski H, Park E, Su N, Ma XJ. Fully automated RNAscope in situ hybridization assays for formalin-fixed paraffin-embedded cells and tissues. J Cell Biochem. 2016;117(10):2201-8. https://doi.org/10.1002/jcb.25606.

25. Wolbers M, Koller MT, Witteman JC, Steyerberg EW. Prognostic models with competing risks: methods and application to coronary risk prediction. Epidemiology. 2009;20(4):555-61. https://doi.org/10.1097/EDE.0b013e3181a39056.

26. Vickers AJ, Elkin EB. Decision curve analysis: a novel method for evaluating prediction models. Med Decis Making. 2006;26(6):565-74. https://doi.org/1 $0.1177 / 0272989 \times 06295361$

27. Chew JL, Loh YH, Zhang W, Chen X, Tam WL, Yeap LS, Li P, Ang YS, Lim B, Robson P, Ng HH. Reciprocal transcriptional regulation of Pou5f1 and Sox2 via the Oct4/Sox2 complex in embryonic stem cells. Mol Cell Biol. 2005; 25(14):6031-46. https://doi.org/10.1128/MCB.25.14.6031-6046.2005.

28. Wilbertz T, Wagner P, Petersen K, Stiedl AC, Scheble VJ, Maier S, Reischl M, Mikut R, Altorki NK, Moch H, Fend F, Staebler A, Bass AJ, Meyerson M, Rubin MA, Soltermann A, Lengerke C, Perner S. SOX2 gene amplification and protein overexpression are associated with better outcome in squamous cell lung cancer. Modern Pathol. 2011;24(7):944-53. https://doi.org/10.1038/ modpathol.2011.49.

29. Ishida H, Kasajima A, Kamei T, Miura T, Oka N, Yazdani S, Ozawa Y, Fujishima F, Sakurada A, Nakamura Y, Tanaka Y, Kurosumi M, Ishikawa Y, Okada Y, Ohuchi N, Sasano H. SOX2 and Rb1 in esophageal small-cell carcinoma: their possible involvement in pathogenesis. Modern Pathol. 2017;30(5):66071. https://doi.org/10.1038/modpathol.2016.222.

30. Masai K, Tsuta K, Kawago M, Tatsumori T, Kinno T, Taniyama T, Yoshida A, Asamura H, Tsuda H. Expression of squamous cell carcinoma markers and adenocarcinoma markers in primary pulmonary neuroendocrine carcinomas. Appl Immunohistochem Mol Morphol. 2013;21(4):292-7. https://doi.org/10.1097/PAl.0b013e31826fd4f3.

31. Ebisu Y, Ishida M, Mizokami T, Kita M, Okada H, Tsuta K. Immunohistochemical analysis of SOX2 expression in small-cell neuroendocrine carcinoma of the endometrium. Mol Clin Oncol. 2020;13(2): 115-8. https://doi.org/10.3892/mco.2020.2051.

32. Zhang XH, Wang $W$, Wang $Y Q$, Zhu L, Ma L. The association of SOX2 with clinical features and prognosis in colorectal cancer: A meta-analysis. Pathol Res Pract. 2020;216(1):152769

33. Munoz N, Bosch FX, de Sanjose S, Herrero R, Castellsague X, Shah KV, Snijders PJ, Meijer CJ, International Agency for Research on Cancer multicenter cervical Cancer study G. Epidemiologic classification of human papillomavirus types associated with cervical cancer. N Engl J Med. 2003; 348(6):518-27. https://doi.org/10.1056/NEJMoa021641.

34. Missaoui N, Hmissa S, Frappart L, Trabelsi A, Ben Abdelkader A, Traore C, Mokni M, Yaacoubi MT, Korbi S. p16INK4A overexpression and HPV infection in uterine cervix adenocarcinoma. Virchows Archiv. 2006;448(5):597-603. https://doi.org/10.1007/s00428-005-0141-x.

35. Muller S, Flores-Staino C, Skyldberg B, Hellstrom AC, Johansson B, Hagmar B, Wallin KL, Andersson S. Expression of p16INK4a and MIB-1 in relation to histopathology and HPV types in cervical adenocarcinoma. Int J Oncol. 2008;32(2):333-40

36. Ishikawa M, Fujii T, Saito M, Nindl I, Ono A, Kubushiro K, Tsukazaki K, Mukai M, Nozawa S. Overexpression of p16 INK4a as an indicator for human papillomavirus oncogenic activity in cervical squamous neoplasia. Int J Gynecol Cancer. 2006;16(1):347-53. https://doi.org/10.1111/j.1525-1438.2006. 00355.x.

37. Yoshimatsu Y, Nakahara T, Tanaka K, Inagawa Y, Narisawa-Saito M, Yugawa T, Ohno SI, Fujita M, Nakagama H, Kiyono T. Roles of the PDZ-binding motif of HPV 16 E6 protein in oncogenic transformation of human cervical keratinocytes. Cancer Sci. 2017;108(7):1303-9. https:/doi.org/10.1111/cas.13264

38. Mills AM, Dirks DC, Poulter MD, Mills SE, Stoler MH. HR-HPV E6/E7 mRNA in situ hybridization: validation against PCR, DNA in situ hybridization, and p16 immunohistochemistry in 102 samples of cervical, vulvar, anal, and head and neck Neoplasia. Am J Surg Pathol. 2017;41(5):607-15. https://doi.org/1 0.1097/PAS.0000000000000800.

39. Chen T, Li J, Wang S, Ning Y, Zhou X, Wang Y. High-risk HPV E6/E7 mRNA in situ hybridization in endocervical glandular neoplasia: performance compared with p16(INK4a) and Ki67 immunochemistry. Am J Transl Res. 2019;11(10):6498-506.

40. Stolnicu S, Barsan I, Hoang L, Patel P, Terinte C, Pesci A, Aviel-Ronen S, Kiyokawa T, Alvarado-Cabrero I, Pike MC, Oliva E, Park K, Soslow RA. International Endocervical adenocarcinoma criteria and classification (IECC): a new Pathogenetic classification for invasive adenocarcinomas of the Endocervix. Am J Surg Pathol. 2018;42(2):214-26. https://doi.org/10.1097/PA S.00000000000000986.

41. Seok J, Ryu CH, Ryu J, Kim JH, Lee SJ, Park WS, Jung YS. Prognostic Implication of SOX2 Expression Associated with p16 in Oropharyngeal Cancer: A Study of Consecutive Tissue Microarrays and TCGA. Biology. 2020; 9(11):387; https://doi.org/10.3390/biology9110387.

42. Martinez-Ramirez I, Del-Castillo-Falconi V, Mitre-Aguilar IB, Amador-Molina A, Carrillo-Garcia A, Langley E, Zentella-Dehesa A, Soto-Reyes E, GarciaCarranca A, Herrera LA, et al. SOX2 as a New Regulator of HPV16 Transcription. Viruses. 2017;9(7):175. https://doi.org/10.3390/v9070175.

\section{Publisher's Note}

Springer Nature remains neutral with regard to jurisdictional claims in published maps and institutional affiliations.
Ready to submit your research? Choose BMC and benefit from:
- fast, convenient online submission
- thorough peer review by experienced researchers in your field
- rapid publication on acceptance
- support for research data, including large and complex data types
- gold Open Access which fosters wider collaboration and increased citations
- maximum visibility for your research: over $100 \mathrm{M}$ website views per year
At BMC, research is always in progress.
Learn more biomedcentral.com/submissions 